\title{
The extraordinary autonomy of sports bodies under Swiss law: lessons to be drawn
}

\author{
Margareta Baddeley ${ }^{1}$
}

Published online: 20 December 2019

(c) The Author(s) 2019

\begin{abstract}
High-profile decisions of the sports governing bodies and subsequent judicial decisions of the Court of Arbitration for Sports (CAS) in Lausanne, the Swiss Federal Tribunal and, sometimes, the European Court of Human Rights frequently draw wide public attention to the fact that in litigations of the sports world, the decisions of the sports governing bodies will generally be upheld on court appeal. This is due to the extraordinary autonomy that sports governing bodies enjoy under Swiss law, deriving on the one hand from the liberal legislations in Switzerland governing associations and arbitration, and on the other hand, from their equally liberal application by the courts, especially in sports-related cases. While the high degree of self-regulation and arbitration in sports allowed the efficient handling of the increasingly complex activities of international sports and of the ever-rising cases of contention among its stakeholders, it is also necessary to point out the flaws of the resulting situation: for the governing bodies of international sports, self-regulation serves primarily the smooth organization of sports, while the specific interests of the subjects of their rules, in particular those of the lower level sports organizations and of athletes, are of secondary importance or may fall completely by the way-side. By contrast, state and international political and judiciary bodies must weigh the interests and rights of all parties involved when regulating relations or deciding in litigation between private parties, so as to ensure that the essential rights of the weaker parties are respected in all situations. This is a heavy responsibility for courts facing the bulk and the power of international sports governing bodies, foremost the Swiss Federal Tribunal, and to a certain extent also the Swiss legislator.
\end{abstract}

Keywords Autonomy · Self-regulation · Swiss association law · Sports governing bodies · Arbitration in sports · Athletes' rights $\cdot$ Personality rights

\section{The question}

On October 2nd, 2018, the European Court of Human Rights (ECtHR) issued its long-awaited decision in the Pechstein \& Mutu case. ${ }^{1}$ In this first ruling of the ECtHR concerning a dispute arising under sports law involving a CAS award, the Court confirms some of the central positions taken previously in such cases by national jurisdictions, in particular by the Swiss Federal Tribunal (SFT), and sets aside the athletes' point of view and arguments. The purpose of this essay ${ }^{2}$ is to

I thank Mr. Anton Sauder, exchange student at our university, for his help in reviewing the text.

Margareta Baddeley

Margareta.Baddeley@unige.ch

1 Professor Emeritus, Faculty of Law, University of Geneva, Geneva, Switzerland discuss the underlying, fundamental question arising from such decisions: why does the Court confirm that arbitration in sports is "forced arbitration" and nevertheless uphold the validity of such arbitration?

The answer lies, on the one hand, in the considerable autonomy afforded the governing bodies of international sports by the Swiss law of associations in combination with Swiss arbitration law, and on the other hand, in the reluctance of Swiss courts of law to intervene in "internal" affairs of the sports world and in arbitration in general. These two factors enhance each other's effect and result in an extraordinary degree of self-regulation in sports, which, as is discussed in Sect. 4, entails a heavy responsibility of the Swiss

\footnotetext{
1 Available at https://hudoc.echr.coe.int/eng\#\{"itemid":["001-18643 $4 "]\}$; for both athletes this ruling terminated more than 10 years of procedures in courts.

2 This is a detailed and updated version of a keynote speech given at the ISLJ Annual international sports law conference 2018 at the ASSER.
} 
Federal Tribunal and international jurisdictions for the protection of the rights of weaker parties in litigation within the sporting world. Provisions on international arbitration being under review by the Swiss legislator presently, there is also room for creating rules specifically adapted to arbitration involving individuals and in particular individuals without legal counsel in the crucial moments of litigation.

\section{The autonomy of the international sports bodies}

\subsection{Swiss association law}

Switzerland counts hundreds of thousands of associations in all venues of life. These corporations range from very small local entities, typically the small club dedicated to its members' cultural or leisure activities, to very big bodies, e.g., the national unions, the Swiss Touring Club and the national, continental and international sports governing bodies. From the point of view of the constituencies, small associations are usually set up by individuals and comprise only or essentially individuals as members. Bigger associations, on the other hand, are generally set up by other associations or other legal entities as an umbrella structure; their members tend to be legal entities, but they can also admit individuals as members. For the purpose of this article, this second type of the association will be called federation-derived from the French title for associations of associations, i.e., federations. Associations and federations ${ }^{3}$ subject to Swiss law are governed by Articles 60-79 of the Swiss Civil Code (SCC). ${ }^{4}$ The main characteristics of Swiss association law as described below were laid down at the beginning of the last century and have remained untouched by subsequent amendments of the SCC.

As per Art. 60 SCC, the creation of an association or federation as legally valid entities independent of their members is subject to few requirements by law: the assembly of founding members has to set out in writing that it intends to create a corporation under the form of an association,

\footnotetext{
3 Only federations of cooperatives are specifically mentioned in legal texts (cf. Art. 921 et seq. Swiss Code of Obligations, SCO; https:// www.admin.ch/opc/en/classified-compilation/19110009/index.html), but federations of associations are generally admitted by courts and in legal literature; Portmann (2005), para 515 et seq. Websites references were valid at the date of closing this article.

${ }^{4}$ https://www.admin.ch/opc/en/classified-compilation/19070042/ index.html. All Swiss laws are published and are valid in three official versions, i.e., in French, German and Italian; some laws are also published in English on the official website. Courts will issue their decisions in one of the official languages; if the interpretation of a provision in this language requires it, the versions in the other official languages can be referred to.
}

the overall purpose of the association and its (expected) resources, e.g., membership fees, donations, revenue from sponsoring (Art. 60 I SCC). The overall purpose of any association must be "non-commercial" (the original legal text read: pas un but economic, nicht wirtschaftliche Aufgaben, fine non economico), which amounts to "non-profit" in the legal language of other countries. However, commercial activities - as opposed to a commercial purpose - of the association do not infringe Art. $60 \mathrm{SCC}$ and therefore do not invalidate the association if they are conducted in order to provide the means to achieve the overall non-profit purpose of the association.

Beyond having to fulfill these basic requirements, associations are very free to set their own rules as to their structure and the functioning of the internal bodies, the rights and obligations of their members and the settlement of internal conflicts. The 20 short articles of Swiss law on associations provide a minimal organizational framework, lay down the basic rights and duties of the members and to settle a few specific questions, in particular concerning bookkeeping standards, auditing and the liability for debts of the association. With a few more statutory rules added, the resulting regulatory regime is generally sufficient for small clubs, established and run by a group of people pursuing common cultural, recreational, charitable and other activities at a local level.

Of higher relevance for the sports world and in particular for the international governing bodies of sports is the possibility for bigger entities to create a more sophisticated framework, with complex rules as to the organization of the association and to the rights and obligations of its members. This possibility exists since the SCC was passed in 1907 and enacted in 1912 and was certainly intended by the lawmaker, aware of the fact that already in the beginning of the twentieth century, national associations with hundreds, some with thousands of members existed-interestingly one of them being the Swiss Alpine Club with 6000 members. ${ }^{5}$

Taking advantage of this freedom, associations must nevertheless spell out the most important rules as to the basic organization of the entity, the powers of its organs and sub-divisions, the essential rights and duties of members, as well references to the rules of other legal persons, if these rules result in important obligations for the members, in the statutes. The statutes can be and generally are completed by the provisions of the bye-laws and by references to (further) rules of other entities, e.g., the rules of WADA or CAS. Reference to the rules of the sports governing bodies is usual also in contracts concluded by sports associations and federation, notably in work contracts of professional athletes or support personnel, and in contracts with event organizers,

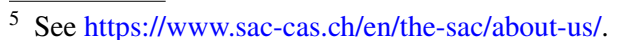


suppliers, sponsors, etc. Incorporation of these rules results in their being binding on members and the contractual parties. Statutes determine the conditions at which the statutory provisions and bye-laws can be changed; for changes of the statutes a majority vote-of at least $2 / 3$ of the votes in most associations - of the Members' Assembly is usually required.

As fully fledged legal persons, associations are also empowered to own or participate in other legal entities (foundations, commercial companies, associations) and to enter into contractual relationships with third parties.

The rules set up by associations and federations are not subject to any preliminary control. As provided by Art. 61 SCC, associations conducting commercial business must register with the Commercial Register, but they already exist as valid legal entities as of the day they fulfill the requirements of Art. $60 \mathrm{SCC}$ as described above. All other associations can, but do not have to, register. In the case of an application for registration, the Office of the Commercial Register conducts a limited review of the statutes to ensure that the necessary components of the statutes exist. The same is true for later modifications of the statutes and bye-laws. In other words, the legality of associations' rules is only fully controlled in the cases where a decision of an association or a dispute between parties involving the rules of an association is challenged in court. Art. 75 SCC, which cannot be overridden by the association's own rules, grants members the right to submit decisions of the association's bodies to an independent and impartial judicial authority.

As will be discussed in detail below under Sect. 2.3, when reviewing such cases, the autonomy of the association will (still) be a major factor for the outcome of the case. As commanded by Art. 63 SCC, the court will base its decision primarily on the provisions of the association pertaining to its relationship with its members, unless mandatory law provides for different rules. The mandatory provisions of Swiss association law, in particular Art. 75 SCC, are aimed at protecting the underlying principle of this legislation, i.e., the democratic spirit of associations which implies some fundamental rights of members. But there are very few mandatory provisions of law which limit the powers of the associations. Art. 63 SCC spells out perfectly that the intention of the legislator was to grant associations large powers of self-regulation.

However, it goes without saying that the rules of an association can only govern its own (internal) affairs and those with third parties who have agreed to submit to the rules of the association. General law cannot be excluded for criminal acts, torts, social security or for dealings with state authorities in general (tax, administrative law, immigration law, etc. $)^{6}$

\subsection{The international sports governing bodies in Switzerland}

Most of the international sports governing bodies are domiciled in Switzerland and set up as associations, subject to Art. 60 ff SCC. Among them, the best known are the International Olympic Committee (IOC) and its dependent associations and federations, the international federations (IFs) of the popular sports like football, basketball, swimming and skiing, as well as the powerful Union of European Football (UEFA). The possibility to create adequate, legally enforceable regulations within a very liberal legal framework was probably one of the determining factors in deciding to choose Switzerland as their seats.

The Olympic organizations and the IFs took full advantage of the large autonomy granted to them under Swiss association law. Over the years and in virtually all sports, rules on the organization of the federations and their subordinate bodies, as well as the rules of their respective game and the rules pertaining to competitions have grown tremendously into elaborate and intricate regulations. They contain statutes of at least dozens of pages and multiple and voluminous bye-laws, completed usually by references to the rules of the World Anti-Doping Agency (WADA; see last paragraph of this section) and by rules on conflict settlement, mostly through arbitral tribunals (see Sect. 3 below). By these means, a tightly woven network of rules is applicable from the top to the bottom of the pyramid of the sports organizations and, of course, to the athletes. This is necessary for the rules to be applied validly throughout the sporting world and therefore of major importance for the functioning of international sports. $^{\text {? }}$

The compliance of international governing bodies in sports with the-very limited-formal legal requirements concerning the statutes was naturally never a problem. However, questions were raised whether the international sports governing bodies meet the substantive condition of the non-profit purpose. This is a prerequisite for becoming a valid association or federation as explained in Sect. 2.1. The answer in Swiss legal scholarship has always been positive on the following grounds: The sports governing bodies' first and utmost aim is to provide the regulations for their sport, organize or support the organization of competitions and promote their sport or even sport in general. These are

\footnotetext{
${ }^{6}$ Except in cases of special agreements with State authorities, which, e.g., the IOC has been able to reach for the status of its personnel.

7 See Baddeley and Landrove (2018), para 32.38 et seq., in particular para 31.31 , for further references.
} 
objectives of non-commercial nature and imply a non-profit purpose. ${ }^{8}$ Undeniably, the international sports governing bodies-as well as the lower federations and associations of the pyramid of organized sports, including clubs-nevertheless dispose of sometimes considerable resources derived from commercial activities, conducted directly or via their subsidiaries or associated commercial and non-commercial entities. But, in contrast to commercial companies, the means at the disposal of the international sports federations are then redistributed without taking into account the financial input of the continental or national federations; in the same vein, subsidies, financial and other support go mostly to financially weak and small countries which generally have contributed neither to the financial resources nor to the activities of superior bodies. The final aim of the international sports governing bodies, just like the one of the small club, is therefore generally still qualified as ideal and the validity of these associations and federations confirmed.

Questions have also been raised in legal literature as to the suitability of the association for entities of the size of the international and big internal sports organizations with important business activities. The original association law of the SCC was not tailored for these entities despite of the existence of some big associations already around the turn of the nineteenth to the twentieth century (see above Sect. 2). Rather than linking the validity of entities as associations to the volume of business conducted, the lawmakers introduced stricter requirements concerning the registration, bookkeeping and audits of very big associations (Art. 61, 69a ff SCC) in 2008. Not many of the sports governing bodies reach the thresholds which would subject them to these rules, but many federations apparently comply voluntarily. ${ }^{9}$

The international sports governing bodies' network also includes arbitral instances, destined to deal with litigation between the actors of the sporting world, in particular the Court of Arbitration for Sports (CAS), placed under the supervision of ICAS (see below Sect. 3.1), as well as the World Anti-Doping agency (WADA). ${ }^{10}$ WADA was created as a Swiss foundation, but is now headquartered in Montreal, Canada, with a subsidiary in Lausanne, Switzerland. It issues the World Anti-doping Code (WADA-C) which contains rules on doping, including prohibited substances and sanctions, and is generally referred to in the regulations of the IFs, the IOC and its affiliated agencies, as well as event organizers.

\footnotetext{
${ }^{8}$ BSK - Heini and Scherrer, Art. 60 N 13 et seq.; Baddeley (1994), p. 27 et seq. To my knowledge, the ideal aim of sports clubs and federations was never put into doubt before courts.

${ }^{9}$ Derchi et al. (2017), p. 25 et seq.; Baddeley (2019), p. 68 et seq.

${ }^{10}$ Cf. https://www.wada-ama.org/en/who-we-are.
}

\subsection{Litigation of the sporting world before arbitration, in Switzerland and abroad}

Until the late 1990s, before arbitration became the almost exclusive method of conflict settlement in sports, disputes were decided by the ordinary courts in Switzerland or abroad. ${ }^{11}$ The Swiss rulings in this field are generally founded on Art. 75 SCC, discussed below, and reflect the high value afforded to the autonomy of associations by the Swiss lawmaker: judges review decisions of associations with reserve ("avec retenue"_-“"mit Zurückhaltung"), sometimes even favorably ("mit Wohlwollen") for the association involved, and uphold them except in cases of (clear) violations of mandatory legal rules and of the statutory provisions of associations. ${ }^{12}$ This attitude appeared to be justified and still does to a certain extent, by the underlying concept of the non-economic aim of associations, as well as the usually small size and reduced volume of commercial dealings of associations.

But Swiss courts took a further step in order to protect the autonomy of sports associations. It denies jurisdiction altogether where the disputed decision of an association concerns what came to be called the Rules of the Game (Spielregeln, règles de jeu). ${ }^{13}$ Underlying this approach to disputes in sports is the vision of sports as being purely a leisure activity, with no legally protected interests at stake. Applying the Rule of the Game theory meant, at least in the early years before the mid-1970s, the exclusion from judicial review of most disputes of the sports world, since the Rules of the Game, as the Swiss courts understood them then, comprised all rules of the sports organizations concerning the practice of sports, e.g., regulations on qualification for competition, on licensing, on transfers and on decisions, including sanctions, during matches or games and beyond. Only a very small part of the disputes between sports associations or federations and their members-typically in relation with the organization and the participation in different bodies of the association, membership fees and the likewas accepted for review by courts, as they would have been coming for any kind of association since, in the view of the

\footnotetext{
11 All SFT rulings are available at https://www.bger.ch/fr/index/ juridiction/jurisdiction-inherit-template/jurisdiction-recht.htm. Lead rulings are listed as "ATF et arrêts CrEDH/BGE und EGMR-Entscheide" (referred to in this article: STF 108 II 340) and the other rulings as "autres arrêts/weitere Urteile" (referred to in this article: STF 4A_248/2019). Rulings are in French, German or Italian, even if the preceding procedure and actions were conducted in another language in which case the documents submitted to the SFT have to be translated into the language used in the proceedings before the SFT.

12 Portmann (2005), para 322.

13 Courts went as far as considering cases of sports associations as not being "business subject to private law" (cf. SFT 97 I 488; 1971). See Baddeley (1994), p. 394 for more examples and references.
} 
courts this category of decisions concerns the application of the Rules of Law (Rechtsregeln, règles de droits).

Courts were comforted in this approach in particular by the considerations of one scholar published in $1973 .{ }^{14}$ Thus, sports organizations enjoyed unlimited freedom in issuing and applying a considerable portion of their rules for many years. A similar perception of sports could also be observed in other countries. In reminiscence of the situation in the early twentieth century, when sports were the pastime of the wealthy and the poorer stratas of society had neither the means nor the time for such activities, a similar reluctance to deal with litigation of the sports world was noticeable abroad too, especially in the UK.

The Swiss courts' approach to disputes within sports associations violates one of the key provisions of Swiss association law, Art. 75 SCC. This mandatory article of law guarantees all members of associations due process by an independent and impartial judge in litigation about the association's decisions which infringe on the rules of the association and mandatory State law. ${ }^{15}$ Art. 75 SCC does not limit the review of cases on the basis of the sector of activity. It was difficult from the start to see any argument in favor of this violation of mandatory law .... by courts. The restraint with which courts evaluate disputed decisions of associations, as explained above, suffices to leave associations a large space for self-regulation and decisions of sports associations challenged in courts may well be upheld depending on the concrete situation. The legitimate interests of sports associations are thus duly taken into consideration, as they are for other types of associations, without leaving the weaker parties in disputes, generally the athletes and small clubs, altogether without the legal protection due.

As of the 1970s, due to the increase in international competitions, the professionalization of top level sports and the involvement of commercial interests, more people and institutions were concerned by the application of the regulations of sports organizations, in particular of those issued by the international governing bodies. Logically, contention within the sporting world grew too. The difference to earlier days was furthermore that in many cases existential issues were at stake for athletes and clubs, the bottom layers of the pyramid of organized sports. Still, it took a while and some external decisions by State courts and the EU instances for the sports

\footnotetext{
14 See in particular SFT 108 II 15 and 103 Ia 410. Dedicated to this distinction and widely followed: Kummer (1973). For a detailed description of the distinction and its consequences, cf. Baddeley (1994), p. 309 et seq, in part. p. 344 et. seq; Portmann (2005) para 291 et. seq. See also SFT decision 108 II 15.

15 For general information on art. 75 SCC, cf. BSK-Anton Heini/Urs Scherrer, Art. 75; and as to its application in sports: Baddeley (1994) p. 309 et seq.
}

governing bodies to adapt their attitudes and regulations to the new situation.

Three key cases before Swiss courts illustrate the problems inherent in the international regulations before these adaptations. Early on, at the beginning of the 1970s, Perroud, a semi-professional football player had to go to court in order to be able to carry on working in sports. He had been prevented from playing for another club after his contract with his previous employer had ended, because the two clubs could not agree on the transfer fee. Regulations allowed the clubs to block an athlete from employment for this reason and courts had to put an end to these rules. ${ }^{16}$ During the 1980s, Sandra Gasser, ${ }^{17}$ a sprinter, was suspended for doping without having been informed of the procedure pending against her and without being allowed to participate. No procedural rules in the applicable regulations protected the rights of the weaker party in internal litigation, to the point that she was not even informed of the outcome of the procedure other than by a telephone call from her club's president. This was the first case where courts insisted on protecting the procedural rights of weaker parties. The SFT "Flaschenwurf" ruling of 1982 raised the question whether sanctions pronounced by the Swiss Football League against two clubs for incidents during a match could be challenged in court. The answer was positive as to the effects of the sanctions which went beyond the match. ${ }^{18}$

As said above, the situation was similar in other countries and raised the same questions for courts and authorities. Some 20 years after the Perroud case, the footballer Bosman submitted a comparable request to the European Court of Justice. He fought for his right to exercise his profession and to see general rules on the free movement of workers applied to his situation, which he was denied by the sports bodies. It is well known that he too won. ${ }^{19}$

The rules applied in these and many other cases were obviously of existential importance for the athletes and clubs. With the heightened publicity of sports events and, consequently, of the decisions of sporting bodies, in particular in matters of transfers of players and of sanctions, the importance of these decisions for the reputation and future careers of the individuals concerned increased. The general

\footnotetext{
$\overline{16}$ SFT 102 II 211.

17 Berner Richteramt III, 22.12.1987, in Revue suisse de jurisprudence 1988 pp. 85-88, and Baddeley (1994) p. 337 f. Although pronounced by a first instance court, this ruling influenced Swiss jurisprudence in sports law matters decisively; many procedural improvements in the rules and the procedures of sports bodies have been inspired by the very clear and strict wording of this ruling which broke with the magnanimous considerations usually expressed.

18 STF 108 II 15 .

19 https://eur-lex.europa.eu/legal-content/DE/TXT/ $\mathrm{PDF} /$ ?uri=CELEX:61993CJ0415\&from $=$ NL.
} 
exclusion from judicial review of a substantial part of the decisions by sports associations and federations without at least a summary evaluation of the concrete situation and the rights of the parties at stake and possibly violated, became increasingly untenable. Progressively, courts changed their approach, both in cases of professional and amateur sports, and granted judicial review in matters previously considered as "irrelevant" in law.

This is the case in particular where the violation of the essential personal rights of individuals (Persönlichkeitsrechte, droits de la personnalité), which are protected by Art. $28 \mathrm{SCC}$, is alleged. ${ }^{20}$ These rights are central in disputes concerning sanctions pronounced by sports associations and federations and in relation with players' transfers. Not allowing an athlete to participate in organized sports, be it in competition or in training, e.g., as a sanction for violating sports regulations, is admissible only if the sanctioning entity can establish a legally valid justification which can be a public interest, the private interest of the federation to sanction undesirable behavior such as doping, cheating or insults and other grounds. Courts do therefore do not necessarily accept athletes' demands and uphold the decisions of the sports organizations if they can establish a preponderant interest on their part which justifies the violation of personal rights the claimant. Nonetheless, the intervention of the courts and the application of State law have been instrumental for the deficiencies in the regulations and procedures to be pointed out and for inducing sports organizations to emerge from the early, unsophisticated ways of dealing with the growing complexity of issues in world sports.

As a consequence, considerable improvements of the internal procedures and the substantive content of the statutes and bye-laws of the sports organizations were achieved over the period 1970-2000. They were mainly of procedural nature in order to guarantee the respect of the athlete's or club's right to be heard, to be granted access to the acts of the procedure, to be able to produce evidence and to obtain written notification of decisions. Such prerogatives which are normal in all venues of life governed by the rule of law guarantee that accusations and sanctions are not unjustified which would amount to a serious violation of the personal rights of the defending party. New material requirements were also followed up on: sanctions and other obligations of members were properly spelled out in the regulations, as well as the obligation for decisions to comply with regulations and to be taken by statutory organs. In particular, the rules of the IFs and the Olympic organizations were completed and the references to the rules of other entities down into the pyramid of sports organization as well as to

$\overline{{ }^{20} \text { Portmann }}$ (2005), para 297 et seq. contractual partners were perfected. ${ }^{21}$ This in turn led to the creation of uniform rules applying to the internal sanctioning processes at all levels, which was of importance for the fight against doping's increase in severity in the early 1990s. The licensing process and transfer of players was also given a better regulatory frame. Last but not least, communication was enhanced among the actors of world sports which had become an absolute necessity taking into consideration the international development of sports on all levels.

As a result of the process of reconsidering the interests involved in sports, by the end of the 1980s State courts had left no doubt as to the fact that rules and decisions of sports associations, including those organizing the sporting activities, can be challenged in court and that, in other words, contrary to the expectations within the sports governing bodies, their autonomy is not unlimited. Given the important interests at stake, it did no longer appear justified to exclude sports-related rule and decisions applying them, in particular concerning contractual relationships in sports, (most) sanctions for the violation of the associations' rules, as well as concerning problems with hooliganism and racism, from judicial review in democratic countries based on the rule of law. Today, if and when disputes of the sports world are submitted to Swiss courts (see on this subject Sect. 3. Below), only decisions of referees on the playing field are considered as irrelevant in law, because they are based on Rules of the Game, and will still not be reviewed by Swiss courts. All other claims are qualified as being based on a dispute concerning the application of a Rule of Law and are reviewed by courts on the basis of Art. 75 SCC. This also transpires in arbitral awards. In the light of these developments, it is astonishing to see the writ of the Swiss government in the cases Mutu \& Pechstein before the ECtHR state that "CAS functions on the basis of an organization and rules totally independent of the State." 22

Similar legal problems as those which Swiss courts had to decide on were faced by jurisdictions in other countries and in particular by the bodies of the European Union. Issues in professional sports, in particular transfers and admissions to competition of players within the European Union and associated countries increased and the sports governing bodies were reigned in to the extent necessary to guarantee the application of EU law, in particular as concerns free

\footnotetext{
${ }^{21}$ In ordinary proceedings before State courts, the formal submission of athletes to the rules of the (higher) sports governing bodies, which are the basis for sanctions, is still controlled by the court; see, e.g., SFT 5A_805/2014, 22.6.2015, para 5.4; for a sanction to be validly pronounced, the athlete must be bound to the governing bodies' regulations (by statutory or contractual clauses) and the sanction must not be disproportional (Art. 28 SCC; paras 5.2 and 5.3).

${ }^{22} \mathrm{~N} 60$ (transl.) : "TAS repose sur une organisation et des normes entièrement indépendantes de l'État.” Cf. fn 1.
} 
movement of workers. ${ }^{23}$ The awareness of the European Union of the issues of the sporting world was of considerable importance for the image of sports changing from that of a legally irrelevant pastime to that of an economic activity with parties in conflict entitled to the protection of the law and the courts.

This being said, self-regulation in sports has by no means come to an end. As to the rulings applying Swiss law, they were only reminders of the overall limits to be respected by any association, and leaving therefore still considerable room for self-regulation. Additionally, sports organizations still benefit from a certain advantage over associations in other fields, with a small, but not unimportant fragment of the Rule of the Game theory still upheld by Swiss courts: jurisdiction will be declined by them for acts and decisions which take place on the playing field and have no effect before and beyond the duration of the game or match, i.e., in particular, the decisions of field referees during the game as to the behavior by players or to the way the game is conducted.

Self-regulation and the liberal approach of Swiss courts to sports also allowed the international sports governing bodies and the lower federations to put in place arbitration as a means to settle conflicts within the sporting community, thus reducing the influence of State law and State courts.

\section{Arbitration: guardian of the autonomy of the international sports bodies}

\subsection{Sport turns to arbitration}

During the 1980s, with the radically changed circumstances in organized sport, contention at all levels of the pyramid of sports bodies increased correspondingly as could be expected. Unsurprisingly too, this complicated the organization of the sporting activities especially if contentious cases ended up before courts and prompted the IFs and the IOC to look for ways to render procedures more efficient.

Reducing cases of ordinary court proceedings and establishing uniform rules to be applied everywhere in the world were the main aims in this endeavor ${ }^{24}$, and arbitration was

\footnotetext{
${ }^{23}$ Cf. Bosman, fn 18 above; Meca Medina \& Majcen (https:// eur-lex.europa.eu/legal-content/EN/TXT/?uri=CELEX:62004 CJ0519); Lehtonen (https://eur-lex.europa.eu/legal-content/EN/ TXT/?qid=1564936560783\&uri=CELEX:61996CJ0176); Walrave \& Koch (https://eur-lex.europa.eu/legal-content/EN/TXT/?qid=15649 36680027\&uri=CELEX:61974CJ0036). See also the decision of the European Commission concerning ISU rules which ban cyclists for life for participating in non-ISU competitions; such bans violate EU anti-trust law; cf. Haas and Strub (2019), p. 75 with references to the EU-C documents.

${ }^{24}$ Lindholm (2019), p. 5 et seq.
}

the answer. ${ }^{25}$ The decisive impetus toward arbitration came from the IOC with the creation in 1984 of the Court of arbitration for Sports $(C A S)$ in Lausanne which, after modest beginnings, is recognized by most IFs at present; some IFs have their own arbitration procedures in place which will not be dealt with in this article. It is important to mention that the inclusion of the WADA- $C^{26}$ in the regulations of the international sports governing bodies in 2003 led to considerably more sanctions being pronounced by the international sports governing bodies, including WADA itself, and consequently to procedures before CAS. ${ }^{27}$ Despite the fact that proceedings before ordinary State courts are not totally excluded, CAS has thus become the major actor in sports dispute settlement. ${ }^{28}$ The consequences are important for the parties in conflict and the sports governing bodies.

\subsection{Swiss arbitration legislation and sports}

Swiss law on arbitration is of paramount importance for this process because CAS has its seat in Switzerland and its awards, even if rendered abroad, ${ }^{29}$ are governed by Swiss arbitration law, international cases by Art. $176 \mathrm{ff}$ of the Swiss Private International Law Act (PILA) ${ }^{30}$ and domestic cases by Art. $353 \mathrm{ff}$ the Swiss Civil Procedure Code (SCPC). ${ }^{31}$ Most challenges of CAS awards before the SFT have been qualified as international, at least one party being domiciled, resident or having its seat abroad. Interestingly, although concerning most certainly international sports, some cases

\footnotetext{
${ }^{25}$ Arbitration had also taken place in earlier years, but on a much lesser scale; only few sports regulations contained arbitration clauses and some of these procedures were based on ad hoc agreements of the parties.

${ }^{26}$ https://www.wada-ama.org/en/what-we-do/the-code.

${ }^{27}$ Lindholm (2019), pp. 61-63.

${ }^{28}$ Which is recognized also by the SFT and leads to its "liberal interpretation" of agreements as to their validity as arbitral clauses or conventions; cf. SFT 4A_314/2017, 28.5.2018, para 2.3.1 (FIM v. Kuwait Motor Sports Club). Arbitration of the CAS can also be imposed by law as well as by the statutes of the sports organizations, e.g., Cameroun, as per SFT 4A_170/2017 \& 4A_194/2017, 22.5.2018, para B.b.a. See also below Sect. 3.2.

${ }^{29}$ Cf. R28 Code of Sports-related Arbitration 2019 (hereafter CASC) and A3 of the Rules of the CAS Anti-Doping Division 2019 (hereafter ADD-C); https://www.tas-cas.org/en/arbitration/code-procedural -rules.html) and https://www.tas-cas.org/en/arbitration/cas-anti-dopin g-division.html). See, e.g., SFT 4A_494/2018, 25.6.2019, concerning proceedings held at Buenos Aires. For details on the ADD, Brägger (2019) pp. 11-18.

${ }^{30}$ https://www.admin.ch/opc/fr/classified-compilation/19870312/ index.html.

31 https://www.admin.ch/opc/en/classified-compilation/20061121/ index.html. Arbitration is internal if it takes place in Switzerland and none of the parties has its domicile, usual residence or seat abroad. In these cases the parties can, however, agree to submit their case to PILA (Art. 353 II SCPC).
} 
were qualified as domestic arbitration, both parties having their domicile or seat in Switzerland, e.g., the high-profile 2017 case Platini v. FIFA. ${ }^{32}$ Since international cases before CAS are by far more frequent, the discussion below concentrates on international cases.

Both PILA and the SCPC are renowned for creating very liberal regimes for arbitration..$^{33}$ The specific provisions are inspired by commercial arbitration and therefore are built on the premise that arbitration takes place by agreement of the parties, who renounce on the fundamental right to refer their dispute to State courts; consent must be free and informed (cf. below Sect. 3.3.2). Any dispute involving economic interests directly or indirectly may be the subject-matter of international arbitration (Art. 177 I PILA); domestic arbitration may concern any claim parties may freely dispose of (Art. $354 \mathrm{SCPC}$ ). Furthermore, the parties decide on the applicable procedure and applicable law; the latter can be non-state law, i.e., regulations of non-governmental bodies, or equity (Art. 182 and 187 PILA, Art. 369 and 381 SCPC). Arbitration replaces the entire ordinary procedure before State courts. By Swiss law, awards can only be challenged before a Swiss appeals court, in principle the Federal Tribunal (Art. 191 PILA, 389 SCPC) and only on a limited number of grounds (Art. 190 II PILA, 393 SCPC). ${ }^{34}$ Under certain conditions, even this reduced challenge can be excluded by the parties in their arbitration convention (Art. 192 PILA). Foreign awards are executed in Switzerland under the conditions of New York Convention of 1958 (Art. 194 PILA). ${ }^{35}$ The liberal regulation of arbitration in Swiss law explains the interest of the international sports bodies for setting up their organizations and arbitration in Switzerland. Certainly, the ECtHR can be called upon for a review of the

\footnotetext{
32 SFT 4A_600/2016, 29.6.2017 (Platini v. FIFA, with explanations of the differences between the two types of arbitration and an in-depth analysis of the domicile of the parties). For other examples, see SFT 4A_338/2018, 28.11.2018 (implying FIFA and commercial companies) and 4A_134/2012, 16.7.2012 (Olympique des Alpes SA v. $U E F A$ et al.). The distinction between international or national arbitration is especially important concerning employment contracts, e.g., between a coach and a club (see SFT SFT 4A_7/2018, 18.4.2018, football) which cannot be decided by an arbitral court if the case is qualified as national.

33 As underlined in SFT 4A_314/2017, 28.5.2018, para 2.3.1, as well as the lead cases SFT 133 III 235 (2007), para 4.3.2.3, and SFT 129 III 445 (2003), para 3.3.3.2.

34 The major grounds invoked by parties in sports litigation are discussed below. The grounds for review of internal awards are less restrictive, both in quantity and as concerns the degree of the State court' jurisdiction (Art. 393 SPCP). The parties may provide for appeals of the awards to be submitted to the cantonal High Court rather than the SFT (Art. 390 SPCP). See Hovaguimian (2018) for criticism as to the lack of review of facts by the SFT, due to Art. 190 PILA.

35 Para 18 ff, 25 and 28 of the SFT Pechstein ruling.
}

SFT ruling under the conditions of the Convention, ${ }^{36}$ but procedures are long and costly. Also, other national courts may have a different stance on these questions, as the Pechstein case showed; execution of foreign decisions is, however, not guaranteed in such cases, especially if a decision by Swiss courts exists too.

Given the underlying legal framework, arbitration in Switzerland was of the greatest interest for sports governing bodies in their quest to submit internal disputes and their settlement to their own rules and to avoid as much as possible reviews by ordinary courts. As mentioned above, the leniency of Swiss arbitration law is rooted in the circumstances of commercial arbitration and it is reinforced by the firmly established position of Swiss jurisprudence tending to intervene as little as possible in sports litigation, including arbitral proceedings.

Yet, in many regards, the situation of the parties and the setup of the arbitral instance are not the same in sports as they are in commercial dealings and classical arbitration, and it does not come as a surprise that the move of the sports governing bodies to exclude nearly entirely the application of State law and the jurisdiction of State courts by referring litigation to arbitration has been and still is questioned by the parties in contention and in legal writing. The questions raised most frequently will be discussed briefly below.

\subsection{Essential questions ... and some answers}

\subsubsection{The independence and impartiality of arbitral courts in general and of CAS in particular}

Swiss association law contains very few mandatory provisions, as explained above in Sect. 2.3. The key one is Art. 75 SCC which reads: "Any member who has not consented to a resolution which infringes the law or the articles of association is entitled by law to challenge such resolution in court within one month of learning thereof." ${ }^{37}$ The question as to whether the "court" referred to in Art. 75 SCC can also be an arbitral jurisdiction, has been answered positively by the SFT, providing the private court is independent of the parties and impartial. ${ }^{38}$ The same conditions have been

\footnotetext{
$\overline{36}$ Cf. ECtHR ruling (fn 1), para 54 et seq., especially para 56 et seq. and 62 et seq.: both Mutu's dispute over damages due to his club, as well as the doping sanction imposed on Pechstein are considered of "civil" (law) nature involving private entities subject to the jurisdiction of the State.

${ }^{37}$ English is not an official language of Switzerland; the English version of the SCC is provided for administration purposes only on the website of the Swiss administration under https://www.admin.ch/opc/ en/classified-compilation/19070042/index.html. For references, cf. fn 18.

${ }^{38}$ SFT 144 III 120, para 1.2.2.
} 
spelled out by the ECtHR, applying Art. 6 I ECHR in the Pechstein case (cf. fn 1).

These conditions are not easy to fulfill in sports arbitration. The jurisdictional instance is usually set up by the national or international federation, which might itself be party to the dispute or close to one of the parties. Naturally, the federation concerned, as well as the IOC, also has a dominant position in its sport. This problem was discussed in detail by the SFT in a case involving the International Equestrian Federation (FEI) and where the Court emitted doubts as to the independence of CAS from the IOC, which could matter in cases with the IOC as one of the parties. As a matter of fact, CAS was organized and financed by the IOC which also had important powers of intervention in the running of CAS and with regard to the arbitral affairs submitted to CAS, in particular the competence to modify the CAS Statute, for the IOC to appoint $25 \%$ of the members of CAS and for the IOC's president another $25 \%$ of the members of the closed list of arbitrators. ${ }^{39}$ The situation was similar for the international or national federations which set up their own arbitral bodies in the 1990s. The question of the independence of the arbitral bodies and of CAS in particular could therefore not be ignored by State courts. In its 1994 landmark ruling in the Gundel case, the SFT stated that it accepted CAS as a valid arbitral court in this litigation, involving the rider and his IF, the international equestrian federation (FEI). The Court also said it would possibly not be able to come to the same conclusion on the validity of CAS if the IOC were to be party in a similar case in the future; the CAS decision would likely be considered an internal decision of the IOC open to ordinary appeals procedures in State courts. ${ }^{40}$

This warning was heard by the IOC which undertook important modifications to the initial CAS setup in force since 1994. They can be summed up as follows: The International Council of Arbitration for Sport (ICAS) was set up as a foundation pursuant to Art. $80 \mathrm{ff} \mathrm{SCC}$, with its seat in Lausanne, Switzerland. Its mission as spelled out in the CAS Code (CAS-C) is to act as the caretaker of CAS instead of the IOC. Consequently, ICAS has to assure the financing of CAS and to oversee the use of the funding (S6.6 CAS-C), the governance of CAS in general (S6 CAS-C), the activities of the CAS Court Office and the CAS Anti-Doping Division

\footnotetext{
39 For a short summary of the complaints in the Gundel case (fn 40) admitted by the SFT, cf. https://www.tas-cas.org/en/general-infor mation/history-of-the-cas.html, section : Organization of the CAS from its creation until 1994.

40 SFT 119 II 271. The IOC or the federation concerned being an association, the ordinary proceedings following Art. 75 SCC and the SCPC would apply, with the competent jurisdictions, i.e., a first instance cantonal court, the cantonal appeals courts and the SFT, having full jurisdiction over the CAS decision.
}

Office (S6.8 CAS-C). Separate procedures were set up, the so-called Ordinary Arbitration Procedure (R38 ff. CAS-C) and the Appeal Arbitration Procedure (R47 ff CAS-C), as well as mediation proceedings. ${ }^{41}$ In 2002, the world governing body in football, FIFA, agreed to submit its disputes to the jurisdiction of CAS, with a specific, reduced list of arbitrators, and in 2019, CAS created an additional Chamber, the CAS Anti-Doping Division with its special rules and a specific list of authorized arbitrators. Parties in litigation have always had to and still have to select their arbitrator from the lists established by ICAS (S6.4, S13, R33 par 2, R48 CASC; A8 par 2 and 3, A 9 ADD-C), but the ordinary list has been increased considerably from the original 60 members to approximately 120 in 1994 and to more than 380 today.

As explained in Sect. 2, the number of cases before CAS grew considerably since its early days and so did the number of challenges of CAS awards before the SFT, ${ }^{42}$ but despite of the changes to the CAS setup since 1994, the independence and impartiality of CAS and of its panels continues to be contested. The validity of CAS panels as arbitral jurisdictions has been confirmed by the SFT in several cases since 1994. A ruling of 2018 even declares that this position must be taken as "fermement établie" (firmly established) and may not be discussed again, which is nevertheless what SFT does-justly_in great detail in that ruling. ${ }^{43}$

The basic position of the highest judicial authority in Switzerland, as presented in this ruling, is nevertheless surprising and might be considered disturbing by some for several reasons because it ignores the reality of arbitration by CAS. The IOC and the international federations undeniably still play an important role within ICAS, and therefore indirectly in CAS. They determine twelve of the twenty members of the ICAS Board, who then determine the remaining eight

\footnotetext{
41 The possibility also introduced then to request consultation of CAS has been abrogated in 2011. Despite of the title of the "appeals procedure," CAS acts in all procedures, except in the 1st instance procedure of CAS ADD, as the first "external" instance in the litigations concerned and its decisions are final, except for the review by the SFT described above. The legal qualification of the $1^{\text {st }}$ instance decisions of CAS ADD is more difficult, since CAS acts there "on behalf of any sports entity which has formally delegated its powers to CAS ADD to conduct anti-doping proceedings and impose applicable sanctions" (A2 CAS ADD-C) and might therefore be qualified legally as a body of the delegating federation. CAS ADD decisions are also subject to appeals to the Appeals Division, under the conditions of rule A21 para 5 ADD-C

${ }^{42}$ See Lindholm (2019), p. 61 et seq., for a summary of these developments and their reasons.

43 See in particular SFT 144 III 120 ("Third party ownership" TPO; FIFA) which retraces the history of the CAS reform and gives the grounds for the SFT's favorable ruling. This judgment refers to the Gundel (fn 39) and other important cases, in particular to the 2003 case Lazutina v. FIS (SFT 129 III 445) and the decision of the German Bundesgerichtshof decision in the Pechstein case (cf. STF 144 III 120, para 3.4.1; ECtHR [fn 1] para 124 et seq.).
} 
members (S5 CAS-C). This Board of twenty members has considerable powers: it adopts and decides on amendments of the CAS Code (S6.1 CAS-C). It elects from among its members its president, who is at the same time president of CAS (S6.2 and 9 CAS-C). It also appoints the members of the three permanent commissions of CAS (S6.3 and S7 CAS-C), the arbitrators which can be chosen by the parties in litigation before CAS (S6.4 CAS-C) and the CAS Secretary General (S6.7 CAS-C) who wields considerable powers, not only in running the CAS office, but also as concerns the individual arbitral proceedings. CAS depends for its financing on the contributions of the parties, but essentially on those of the international sports governing bodies: the total contributions of the IOC and the international federations amount to more than half of the budget of CAS. ${ }^{44}$ The regulations of the international sports governing bodies constitute the applicable law in most litigations decided by CAS (see also below Sect. 3.3.3).

In other words, despite of the shift of certain functions to ICAS, the situation has not changed fundamentally from what it was before Gundel: the international sports governing bodies continue to determine the regulations in their sports and the Olympic events and to finance a sizable part of the costs of ICAS and CAS. Athlete's interests are barely mentioned in the CAS Code (cf., e.g., S4 d CAS-C), the content of which shows that the interest of the parties opposing sports governing bodies in litigation is largely subordinate to the interest of the latter in the smooth running of organized sports. Representatives of the athletes and of the lower ranks of the pyramid of sports organizations are largely absent in the ICAS and CAS setup. The influence of the sports governing bodies remains tangible in general and specifically as to the arbitrators at the disposal of the parties, as explained above. Certainly, the members of ICAS and the arbitrators on the closed lists must declare to "exercise their function personally, with total objectivity and independence, in conformity" with the CAS Code (S5.2, S18 par.2 CAS-C) and arbitrators on the panels may of course be challenged. Nonetheless, the choice of arbitrators remains restricted to the list set up by ICAS and the increase in the number of arbitrators to beyond 380 had a lesser impact than the sheer figures suggest for several reasons. In football disputes, parties have to choose their arbitrator from a list comprising only 102 names, and the arbitrators for the ADD Chamber whose names are not yet published

\footnotetext{
$\overline{44}$ CHF 7.5 mio. of CHF 16 mio., as per STF 144 III 120, para 3.4.3.
} See also para 3.3.3.2, para $8 \mathrm{ff}$, of the Lazutina ruling (fn 43). on the website of CAS at the time of writing this article, i.e., August 2019, will also represent a selection of the arbitrators of the general list as per the ADD-C. Statistics also show that over the years, only very few arbitrators of the arbitrators on the general list have actually served on panels, with a core of repeatedly appointed arbitrators amounting to less than 20 persons. ${ }^{45}$

These facts have also been discussed in the ECtHR ruling in the Pechstein \& Mutu cases of 2018 (fn 1). Under Art. 6 I ECHR a private jurisdiction can be recognized as a court of law under certain conditions, in particular if the independence and the impartiality of the court are assured. Three of the five judges considered this latter condition as having been met because no proof of a bias by any judge on the list and on the panel had been offered by the appellant (para 157 of the ruling). Two judges gave a joint dissenting opinion on this point because the majority decision of the Court was not reached on the basis of the usual criteria which would have meant that the objective impartiality and organizational independence of CAS as an institutionalized court would have had to be established, not only the independence of the individual arbitrators. Only its objective independence would prove that CAS is not under the influence of the IOC and the IFs. In the eyes of the dissenting judges, this was not the case and the conclusion, on this basis, would have had to be that CAS is too dependent on the international sports governing bodies and can therefore not be qualified as a valid arbitral court (para 12-16 and 28 Dissenting opinion; DO). Interestingly, the dissenting judges also criticized the closed list justified by the sports governing bodies and supported by the SFT with the argument that CAS arbitrators need to be specialists in sports law and the organization of sport in order to fully comprehend the cases submitted from a technical point of view. The judges found this not convincing: parties may choose freely their arbitrators in much more technical fields such as the pharmaceutical sector and aeronautics (para 14 DO) ${ }^{46}$ In such cases, arbitral and State tribunals generally

\footnotetext{
45 Lindholm (2019), chap. 8, p. 219 et seq., especially p. 222 et seq., as well as p. 16 et seq. as to the basic principles applied in this research. The reduced number of active arbitrators is due, of course, to the choices made by the parties, but also to CAS's procedural rules and to its own choices governed by the wish to establish coherent case law.

46 The dissident opinion also considered that the Court ruling should have justified in more detail its opinion that CAS is a "court of law" (para 18-25 DO; fn 1). See also Scherrer (2018), as well as Lindholm (2019) p. 221.
} 
revert to experts in order to gain sufficient competence to take their decisions.

The purpose of this demonstration is not to put the personal integrity of the CAS arbitrators in doubt. ${ }^{47}$ It is to show the undeniable weight of the sports governing bodies in ICAS and CAS, which also characterizes the individual arbitral proceedings and influences the applicable regulations. It does not appear far-fetched to consider that CAS and the panels in arbitral proceedings do not fulfill ordinary standards of independence and impartiality and that under these circumstances some litigants might not find an arbitrator on the CAS lists who they feel confidence in. Especially athletes who generally are young individuals with no or hardly any experience in business, litigation and courts, might not feel comfortable with arbitration altogether. These considerations should lead legislators and courts to make sure by the means at their disposal that the weaker parties in litigation are not deprived of the protection of their rights. Such means might be, among others, refusing to recognize an award as such and allowing a challenge in ordinary judicial proceedings based on Art. $75 \mathrm{CC}$, or adapting the rules governing the review of awards to improve the protection of athletes, e.g., by extending the list of grounds for challenges. Regrettably, the trend goes the opposite way.

\subsubsection{The free and informed consent to arbitration}

Arbitration must be agreed upon by the parties, otherwise the right to a decision by a State court in ordinary proceedings remains in effect (Art. 75 SCC, Art. 30 I of the Swiss Federal Constitution, ${ }^{48}$ Art. 6 § I ECHR). A challenge of the jurisdiction of the arbitral court because of the lack of consent must be raised without delay by the contesting party. The SFT also accepts arbitration clauses in the statutes of an association or corporation or in a contract, because as per Art. 178 PILA the agreement must be established in writing, but does not need to be signed by (all) the parties. ${ }^{49}$ The

\footnotetext{
$\overline{47}$ It should be underlined that the institution and the arbitrators must be qualified separately. Examples of CAS panels diverging from the previous decisions of the IFs' or IOC's internal bodies exist. The most spectacular one being the 42 CAS awards in the Russian Doping affair which invalidate partly the preceding sanctions of the IOC Doping Commission; which led the president of the IOC to officially criticize CAS and the SFT ruling which confirmed the award on the basis of Art. 190 PILA; cf. https://www.olympic.org/news/ioc-disappoint ed-at-decision-of-swiss-federal-tribunal. See also Brägger (2018), pp. 135 et seq. and 145 .

48 https://www.admin.ch/opc/en/classified-compilation/19995395/ index.html.

49 See below fn 60 for examples of rulings which also trace the limits of validity of arbitration clauses in statutes and contracts. Among the modifications under discussion of chapter 12 PILA on arbitration, a new para 4 to Art. 178 is proposed which would spell out this possibility.
}

consent to arbitration must nevertheless always be a free and informed one and must cover the scope of the case actually submitted to the arbitral court.

Regulations and contracts in sports generally contain (broad) arbitration clauses. Gaps in this respect which existed in the early stages of arbitration in sports have largely been eliminated since. This still leaves the question open in general and in the specific cases if the consent of all parties is free and informed.

Legal requirements and rulings in this respect vary between courts and countries, as the Pechstein case illustrated very well. The Munich Appeals Court accepted its jurisdiction in this case, considering that forcing athletes to arbitration before CAS constitutes an abuse of the international federations' dominant position. This ruling was canceled by the German Bundesgericht who found that despite of the dominant position of the international federation, the athlete had given her consent freely and CAS therefore had jurisdiction.$^{50}$ In its appeal decision, the ECtHR did not see things the same way as the German Bundesgericht, although it too did not cancel the CAS award. The ECtHR recognizes the usefulness of arbitration in certain circumstances, e.g., in sports (para $98 \mathrm{f}$ ) - it follows the stance of the SFT on this account-, but also admits that athletes are forced to accept arbitration (para $103 \mathrm{ff}, 109 \mathrm{ff}$ and 147) and that they are under much more pressure to accept arbitration than persons and entities in business (para 108). This nevertheless does not lead the Court to deny CAS jurisdiction and cancel the award outright; instead, it insists on the requirement that the arbitral court must be truly independent of the parties and impartial (paras $77 \mathrm{ff}, 92 \mathrm{ff}$ and $148 \mathrm{ff}$ ), which was admitted in this case (above Sect. 3.3.1).

In sports arbitration, the SFT holds a very liberal position both as concerns the form of the agreement and the proof of a valid consent by all parties. ${ }^{51}$ The complacent benevolence ("Wohlwollen") it shows as to statutory and contractual arbitration clauses in sports "aims at furthering the rapid resolution of conflicts by specialized courts which guarantee sufficient independence and impartiality as does CAS." 52 Already in early rulings in cases of the sports world, it held that the athlete, by not contesting or trying to change the arbitral clauses in the statutes or contracts, had validly accepted arbitration. ${ }^{53}$ More recently, it has justified

\footnotetext{
${ }^{50}$ See para 24 of the ruling (fn 1 ).

51 While applying a more restrictive regime for arbitration in other fields, as explained by Zimmerman (2014), p. 12 et seq.

52 Cf. SFT 4A_314/2017, 28.5.2019, para 2.2.1; in this case opposing two motorcycling federations, the ruling discusses essentially the validity of statutory arbitrations clauses. See also SFT 138 III 29 para 2.2.2.

53 Cf. SFT 4P.230/2000, 7.2.2000, Stanley Roberts v. FIBA, para 2a) with references to earlier rulings.
} 
the acceptance of the arbitral clauses in favor of CAS by the fact that such statutory clauses have become "branchentypisch" (usual in this sector of activities) in sports at all levels which implies that these clauses are generally validly accepted by the members and the contractual partners of the sports bodies without a specific declaration to this effect. ${ }^{54}$ Even a party who contests the competence of CAS from the start of arbitral proceedings has therefore little chance of success in invoking the absence of consent to arbitration.

The SFT's position on the validity of the consent by athletes to the rules of sports organizations includes, as explained in the preceding paragraph, consent to arbitration, but not the consent to waivers of the right to challenge the awards before the SFT. As per Art. 192 I PILA, such waivers can be agreed to by the parties, but the SFT requires a specific agreement by athlete for the waiver to be valid as laid out in its Cañas ruling of 2007. ${ }^{55}$ The reason for this strict position is that many CAS decisions, especially those pertaining to non-pecuniary sanctions or eligibility for competitions, do not need any assistance by State courts or agencies for execution. In case a waiver of appeal has been agreed, it will leave the athlete without the possibility of any review by a State court of awards which might uphold decisions violating the fundamental rights of the athlete. Interestingly athletes' rights taken into consideration on this issue do not carry the same weight in argumentations as to other aspects of arbitration in sports (see above Sect. 3.3.1 and below Sect. 3.3.3).

The present discussion about the validity of arbitral clauses in statutes and contracts in organized sports needs to be enlarged to the requirement of informed consent. It is probably true, especially in high level competition, that athletes and clubs are generally aware of arbitration being the usual mode of resolution of conflicts nowadays. It remains doubtful nevertheless that it is generally understood by the athletes and smaller entities in sports, in which way ordinary court proceedings and arbitration differ and the implication of this difference for the situation of the weaker party in litigation. ${ }^{56}$ Age, experience, education, language and the general environment in which athletes live probably result in few of the athletes being properly informed about these statutory or contractual clauses, both when they join organized sport and in case of litigation. In many cases, apart

\footnotetext{
${ }^{54}$ STF 4A_314/2017, 28.5.2018, para 2.3.1; jurisdiction of CAS was not given in the dispute between the FIM and the Kuwait Motor Sports Club, a candidate for membership in FIM. See also STF 4A_490/2017, 2.2.2018, para 3.2.1.

55 SFT 133 III 235 para 4.3.2. For details on Art. 192 PILA and the impact of the SFT decision, cf. Baddeley (2007) p. 160 et seq. The CAS-C reflects this requirement in R59 para 4.

56 Cf. Baddeley (1994), p. 281 et seq., with references to other authors.
}

from not being free, the consent given has probably also not been informed.

Invalid consent to arbitration allows the parties to either conclude a valid arbitration agreement or to refuse arbitration and to submit their case to the ordinary State courts. The consequences of the choice are far reaching: the applicable law is not the same.

\subsubsection{Applicable law in arbitration proceedings and appeals}

The final outcome of each litigation depends very much on the laws and rules applied in the arbitration and the appeals procedures, which are largely at the disposal of parties in arbitral proceedings in general; the situation in arbitration in sports is not quite the same. ${ }^{57}$ In ordinary CAS procedures, the parties choose the applicable law (R45 CAS-C). In the Appeals Procedures of CAS, the regulations of the IF concerned or of the IOC are imposed as applicable law by R58 CAS-C; State law may (only) be applied to fill gaps in the sports regulations. The rules of the ADD seem to widen the choice in the first instance procedures (A2 and A20 ADDC). However, in view of the wording of these provisions, it will have to be seen how they are to be applied, in particular, if the parties may agree to choose, e.g., Swiss law as applicable law instead of the "applicable anti-doping rules." Appeals against the ADD decisions are governed by R58 CAS-C and subject to the rules of the IF concerned or of the IOC (A2 para 3 ADD). This might prove problematic if State law has been chosen by the parties in the first instance proceeding.

CAS panels who decide on the basis of the regulations of an IF, the IOC or WADA may correct contested decisions which do not apply the relevant regulation or apply it incorrectly. Thus, CAS reviewed with severity in particular the proof of doping and the application of statutory sanctions in the Russian doping cases preceding the Pyeongchang Olympics 2018 and declared, contrary to the IOC, the athletes as eligible. ${ }^{58}$ In the Valverde case of 2011, the SFT went as far as to say that, in its view, CAS could even cancel the contested decision of the IF's disciplinary organ and decide in its place. ${ }^{59}$ If the regulations of a sports body are applicable law, as is the case in disciplinary matters submitted to arbitration by CAS, State law not being applied, mandatory

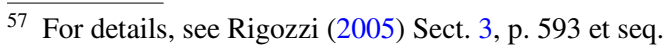

58 Scherrer (2018) p. 122 f.; Brägger (2018) pp. 137, 139, 142 et seq., 144 et seq.

59 This may pose problem as to the role of CAS: last instance of the IF's sanctioning process or arbitral court reviewing the validity of a final internal decision. Cf. Besson (2013), p. 295 et. seq.
} 
provisions of State law are not necessarily enforced in arbitration in sports which changes the way in which the interests of the parties in contention taken in consideration and which weigh they carry if they are.

This aspect is of utmost importance for athletes if their personal rights are concerned, which is regularly the case of disciplinary sanctions and decisions of eligibility. The following example can illustrate this problem. The WADA-C prescribes sanctions and allows their reduction if mitigating factors as described in the Code exist. Just like State law, the principle of proportionality is applied. The CAS decision will nevertheless differ from an equivalent ruling applying State law. Frequently, questions such as the effect of the doping substance found in the athlete's body, the gravity of the athlete's fault, which in its turn is influenced by the age, the education and the general situation of the athlete, and the effect of the sanction on his or her career and therefore on his or her professional and personal development may not be investigated or judged the same way as under State law. The understanding of the principle of proportionality is not the same in sports regulations and in Swiss civil law ${ }^{60}$ and therefore CAS, by upholding, as it must do, the sanction of an IF or the IOC infringes mandatory State law. For example, the severity of the standard 4-year suspension for some doping offense, which amounts to ending the sporting career of a young person just as a life-long ban would, is certainly questionable in this light. Rules on gender discriminations and their justification, especially in view of the correct application of the principle of proportionality, will have to be discussed in depth if the rights of the persons concerned are to be guaranteed.

The SFT generally sets aside CAS decisions only exceptionally. The restrictions imposed by Art. 190 PILA on its review of arbitral awards leaves the SFT little room for correcting violations of mandatory State law resulting from decisions in sports. The generally benevolent attitude of the SFT toward sports and its autonomy reinforces the effect of PILA. Of the few awards set aside by the SFT, all but one presented procedural flaws. ${ }^{61}$ The violation of substantive public order was only admitted once by the SFT, in the Matuzalem case of $2012 .{ }^{62}$ The threshold to reach for

\footnotetext{
${ }^{60}$ For the application of Art. 28 SCC in ordinary court proceeding in a case of a sanction for doping, see SFT 5A_805/2014, 22.6.2015, especially paras 5.2 and 5.3. See also Rigozzi (2005), pp. 649 et. seq., 732 et seq.; Exner (2018), p. 128 et seq.; Morgan (2013), p. 346 et seq., as well as Rietiker (2013), p. 272 et seq., concerning the application of the ECHR

${ }^{61}$ E.g., SFT 140 III 520 (2014; lack of jurisdiction of CAS ratione personae); SFT 4A 627/2012, 8.3.2012 (Ice-Hockey, no extension of the arbitral clauses to third parties); SFT 4A_456/2009, 3.5.2010 (Thys; no jurisdiction); 4A_490/2009, 13.4.2010 (Benfica Lisbon, res judicata).

62 SFT 138 III 322
}

setting aside awards on this ground is very high, considerably higher than the prohibition of arbitrariness which allows awards in internal cases to be set aside. In international cases, the award must disregard essential and broadly recognized values which constitute the basis of any legal order and are as such generally accepted in Switzerland. In order to establish whether the award fulfills this condition, the SFT applies criteria rooted in classical arbitration: the respect of contractual obligation (pacta sunt servanda), of the rules of good faith and of the prohibition of abuse of rights, the protection of incompetent persons and the prohibition of discriminatory and confiscatory measures. ${ }^{63}$ Without the violation of the rights of personality despite of their very high value in civil law, sanctions and other decision in the field of sport rarely reach the required severity and intensity. The Matuzalem ruling sets aside the relevant CAS award because of the resulting excessive restriction of the player's economic and personal freedom. It seemed to open the way to a more adequate interpretation of Art. 190 PILA in cases of the sports world, but it proved to be and remain an exception. ${ }^{64}$

This is most regrettable. Contrary to jurisprudence before arbitration replaced proceedings in State courts, no correction worth speaking of has been made of decisions of sports authorities, and mandatory law, including provisions protection weaker parties in an unequal relation, is not applied. Is this acceptable in a democratic society which normally protects such parties specially? Does sports need such a protection of its own actions to succeed in its mission and in achieving its aims $?^{65}$

\section{Conclusion: the responsibility for the protection of the rights of the weaker parties in sports litigation lies with the courts and the legislator}

The majority of the international sports governing bodies being Swiss associations governed by the Art. $60 \mathrm{ff} \mathrm{SCC}$ benefit from a particularly large degree of autonomy in determining their organization and their rules. Recourse to arbitration, to CAS in particular, for the settlement of internal conflicts has enhanced these advantages, as has the

\footnotetext{
${ }^{63}$ Cf. SFT 4A_312/2017, 27.11.2017, para 3. See also CR - Bucher, Art. $190 \mathrm{~N} 129 \mathrm{ff}$

${ }^{64}$ SFT 138 III 322, para 4.3.1. The SFT underlines especially that the principles applied have to be respected also by the international sports governing bodies (para 4.3.3).

${ }^{65}$ Cf. Exner (2018), p. 137, as to the justification of the 4-year bans in view of the overall aims of sanctions. Critical also of the narrow and often inadequate angle adopted by the SFT, CR - Bucher, Art. 190 N 105 ff. See also Chappelet (2017), p. 13 et seq.
} 
favorable attitude of Swiss courts to sports associations and arbitration in sports. This way, conflicts in sports are dealt with efficiently and largely in a uniform manner. However, like all self-regulation, the rules of the sports governing bodies serve primarily the purposes of their issuers, while the legitimate interests and rights of the persons or other entities subject to these rules and impacted by them is not always being adequately taken into consideration.

In view of the development of the regulations of the international sports governing bodies, it appears necessary to reverse the tendency of the last 20 years to ever increase the autonomy of the sports governing bodies if the essential rights of weaker parties in litigations of the sporting world and more generally of the participants in organized sports are to remain protected. A change of the established practices is all the more urgent that new questions arise f.ex. about e-sports, match fixing, corruption, data protection and gender discrimination and must be dealt with by the sports governing bodies. More intricate aspects of personality rights will become apparent and need adequate answers.

The responsibility to review the rules and the decisions of the sports governing bodies and the arbitral awards in sports disputes lies primarily with the SFT, the ECtHR, the European institutions and with the Swiss legislator. Their's is the duty to protect the fundamental rights of the stakeholders in modern sports and to maintain the minimal standards of law in regulations and procedures.

To achieve these goals, more scrutiny of the regulations and especially of the decisions of sports governing bodies by the courts is unavoidable. The aim must be to make sure that all parties entered into arbitration by their free and informed will and that principles and procedures applied by arbitral courts are in conformity with the applicable legal provisions, in Switzerland and abroad. Athletes, especially the young and inexperienced ones, must be informed in the language of the individual concerned and in terms accessible to him or her as to the nature of the rules they allegedly infringed, the proceedings, the choices parties have, their procedural rights and the means and ways to challenge the decisions taken and to come. Given the unequal weight of parties in sports contention in general, courts must be critical too of the formulation and the scope of the rules applied which are not to exceed, as far as prohibitions and sanctions are concerned, the absolutely necessary for maintaining sport clean and honest and which must also leave room for the presumption of innocence and the application of principle of proportionality in each case.

However, these actions will not suffice to reach the aims stated above. Three facts justify further developments of jurisprudence and law: the first being, that Swiss law-as is possibly the case of the regulations in other countries-is tailored to fit commercial arbitration, the second, that parties in sports are forced into arbitration where their weights are by no means equal, and the third, that arbitration in useful in sports. Therefore, enhancing the possibilities of review of arbitral awards by State courts appears justified. For Switzerland, a new, more comprehensive interpretation of the provisions of PILA, in particular of Art. $190 \mathrm{II}$ e, or a corresponding, formal modification of these provisions by the Swiss legislator would be an important step in the right direction.

Open Access This article is licensed under a Creative Commons Attribution 4.0 International License, which permits use, sharing, adaptation, distribution and reproduction in any medium or format, as long as you give appropriate credit to the original author(s) and the source, provide a link to the Creative Commons licence, and indicate if changes were made. The images or other third party material in this article are included in the article's Creative Commons licence, unless indicated otherwise in a credit line to the material. If material is not included in the article's Creative Commons licence and your intended use is not permitted by statutory regulation or exceeds the permitted use, you will need to obtain permission directly from the copyright holder. To view a copy of this licence, visit http://creativecommons.org/licenses/by/4.0/.

\section{References}

Baddeley M (1994) L'association sportive face au droit. Helbing \& Lichtenhahn, Bâle

Baddeley M (2007) La decision Cañas: Nouvelles règles du jeu pour l'arbitrage international du sport, Causasport, Zurich, pp 155-163 (including an English abstract of the article)

Baddeley M (2019) La forme sociale_-garantie de la bonne gouvernance de l'association sportive? In: Le système olympique. Passé, présent futur, Presses polytechniques et universitaires, Lausanne, pp 59-78

Baddeley M, Landrove JC (2018) Schiedsgerichtsbarkeit in Sachen Sport in der Schweiz, Die internationalen Sportverbände und der Court of Arbitration (CAS) im Schweizer Recht. In: Handbuch Schiedsrecht, Cernich/Deixler-Hübner/Schauer (eds) Manz, Wien, pp 913-950

Besson S (2013) Gouvernance des organisations sportives: importance du droit suisse, enjeux et perspectives. Revue de droit suisse 132 I, Helbing Lichtenhahn, Basle, pp 283-300

Brägger R (2018) Erste Urteilsbegründungen des CAS in den "russischen Doping-Fällen”. Causasport, Zurich, pp 135-145

Brägger R (2019) Die neue “Anti-Doping Division” des Court of Arbitration for Sport (CAS) und weitere Änderungen im CAS-Code 2019. Causasport, Zurich, pp 11-20

Bucher A (ed) (2011) Commentaire romand. Loi sur le droit international privé. Convention de Lugano. Helbing \& Lichtenhahn, Basle (references in text : CR - Author, Art., N)

Chappelet JL (2017) Switzerland's responsibility in the regulation of international sport. In: Landrove JC, Hendriks G (eds) Collected insights, vol 3: governance and ethics. AISTS, Lausanne, pp 12-16

Derchi GB, Davila A, Oyon D (2017) Corporate governance. Challenges for international sports federations. In: Landrove JC, Hendriks G (eds) Collected insights, vol 3: governance and ethics. AISTS, Lausanne, pp 19-29

Exner J (2018) Anti-doping and athletes' rights under EU law: fouryear period of ineligibility as disproportionate sanction? Int Sports Law J 17:128-138 
Haas U, Strub Y (2019) Entwicklungen im Sportrecht. Causasport, Zurich, pp 76-81

Honsell et al (eds) (2014) Basler Kommentar, Zivilgesetzbuch I, 5th edn. Helbing \& Lichtenhahn, Basle (references in text : BSK Author, Art., N)

Hovaguimian P (2018) Non-reviewable Facts in Swiss Annulment Proceedings: Undermining the Safeguards of Art. 190 PILA, ASA Bulletin 36, I-ASA-CH \& Kluwer Law International, pp 89-108

Kummer M (1973) Spielregel und Rechtsregel. Staempfli, Berne

Lindholm J (2019) The court of arbitration for sport and its jurisprudence. Asser/Springer, The Hague/Berlin

Morgan M (2013) The relevance of Swiss law in doping disputes, in particular from the perspective of personality rights-a view from abroad. Revue de droit Suisse I:341-351

Portmann W (2005) Das Schweizerische Vereinsrecht, Schweizerisches Privatrecht, vol 5. Helbing \& Lichtenhahn, Basel et al
Rietiker D (2013) Introduire une requête à la Cour européenne des droits de l'homme. Revue de droit Suisse I:259-281

Rigozzi A (2005) L'arbitrage International en matière du sport. Helbing \& Lichtenhahn, Bâle

Scherrer U (2018) Im Vorfeld von Olympia : IOK-Pleite vor der "Haus"-Gerichtsinstanz. Causasport, Zurich, pp 122-123

Zimmermann M (2014) In dubio pro Schiedsgerichtsbarkeit?. Causasport, Zurich, pp 11-20

Publisher's Note Springer Nature remains neutral with regard to jurisdictional claims in published maps and institutional affiliations. 